\title{
Raising AWareness around Writers' Voice In ACADEMIC Discourse: An Analysis of Writers' (IN)VISIBILITY
}

\begin{abstract}
This paper aims to contribute to the study of the concept of writer's visibility inspired by approaches to the analysis of identity in written discourse (see Ivanič 1998, Charles 1999 and John 2005). The way medical academic writers selfrepresent themselves in their research articles can be seen in terms of a gradable visibility cline crafted and constrained by the academic genre expectations of these texts (Swales and Feak 2004; Stock and Eik-Nes 2016). Traditionally, authorial visibility has been studied within frameworks such as evaluation, authorial voice and stance. Still, there is no framework as yet been proposed that binds together possible textual realisations that can be considered as visibility features in academic written texts. This paper conducts a study of 40 medical research articles that reveal different manifestations of the authors' presence. A cline is proposed that encompasses different lexico-grammatical realisations such as self-mentions, passive constructions and non-animated subjects followed by active verbs. These features can be interpreted as authorial voice realisations that allow us to measure or grade writers' visibility and its rhetorical implication in the text.
\end{abstract}

\section{Keywords}

Voice; visibility; self-representation awareness; academic discourse analysis; academic writing

\section{Introduction}

The field of identity or self-representation in academic writing has received much attention from the 1990s. It mainly began with Ivanič's (1998) Writing and Identity. 
Identity is a multifaceted term that has been approached from different inspiring views. Foucault (1972), for instance, exemplifies how identity is alienated by the dominant discourses of the academia or the institutions - just as novice writers' first incursions in a research field. Besides, Fairclough $(1992,1995)$ believes that the identity of any writer may be affected by other dominant identities. Hence, the idea of power and the ensued relations embedded in different social, ethnic or literary cannons, for instance, shape for good or for bad, both discourse and the self-identity of a writer. One of the most prolific strands of research based on the concept of writers' identity in Applied Linguistics focuses on the academic writers' construction of that identity (cf. Stock and Eik-Nes 2016). In this avenue of research, awareness has been raised about the issue of the real self and the artificial imposed identities adopted in writing. Some scholars stated that constructing identity when writing was just a "performance" (Butler 1990). Nevertheless, Ivanič (1998) observes that some linguistic and textual choices made by writers in their texts - being these choices imposed or even expected by the generic conventions of the texts (Swales and Feak 2004; Matsuda and Tardy 2007), should be interpreted as realizations of the writers' self. We can agree that the writers' identity is finally perceived, negotiated and interpreted by a potential readership while reading the writers' texts. To allow readers to get to such interpretations writers use certain linguistic and textual features to show the potential audience their proximity, attitude or even commitment regarding what is conveyed in the text. Rather than investigating how to reveal or obscure the writers' identity (Charles 2006), this study reflects on how to uncover the extent of writers' (in)visibility raising awareness on the concept of writers' voice (John 2009) and how this voice can be measured (Dressen-Hammouda 2014). The realisations of the writers' voice can then be qualitative and quantitative interpreted revealing the degree of (in)visibility of the writer, in this case in medical research articles (henceforward Med-RAs). In this paper, a cline will be proposed for the analysis of that visibility in line with inspiring previous research (see Tang and John 1999; John 2007; Lorés-Sanz 2008 and Bordet 2013) and its further interpretation.

Sections 1.1 and 1.2 below explain what is here understood as the notion of writers' voice and how the realisations of that voice (un)veil writers' (in)visibility and their ensuing presence in Med-RAs.

\subsection{Towards a conceptualization of visibility and voice of Med-RAs writers}

Based on Ivanič's (1998) approach to the conceptualization of writer's identity, John observes (2005) that the concept of self is the first detail that comes to readers' minds when we notice any trace of writers' identity projection in a written text. Aligned with this premise (Tang and John 1999; John 2005) this study understands that when writers display their mental processes, ideas and knowledge in their texts, they admit to having and projecting their voice in these written texts. Discrepancy between the academic conceptualisations of voice should therefore be addressed here for the sake of clarity. This section first reviews scholarly dis- 
crepancy regarding the polysemous conceptualisation of voice in some written discourse studies, a notion which seems to be underexplored in academic writing research. In order to become communicatively effective, and therefore build our texts credibility, writers' self-representation deserves intent attention in any writing process.

It should be considered that the use of the term voice in Applied Linguistics emerged in the late 1960's. Bowden (1995) explains how this metaphor of spoken voice was a concept used by several scholars as a voice that could be heard by readers while reading a text (Elbow 1994). Matsuda (2001: 41) suggests that we should approach this phenomenon as "the amalgamative effect of the use of discursive and non-discursive features that language users choose, deliberately or otherwise, to form socially available yet ever-changing repertoires". Although these orientations are up for debate, most scholars agree that the notion of voice comprises both individual and social dimensions. According to Elbow (1994), we modulate our voices in different contexts, for different purposes and also considering the people we are speaking to. In Tardy's (2012) view, writers can choose certain discourses to align (or not) their voice within a particular work or text. Moreover, a social view of voice also suggests, as Burgess and Ivanič (2010) do, that voice is inevitable in written texts. Even though writers intend to self-represent themselves as invisible, there is still an audible and therefore interpretable voice since voice is not simply own by the writers, but constructed by the social world the writers are embedded (Ivanič 1998; Prior 2001; Petrić 2010).

How some linguistic and rhetorical features can be associated with the socalled broad notion of voice and the consequent writers' visibility phenomenon have lately enjoyed research attention in general in the field of Applied Linguistics (Tang and John 1999; Charles 1999; Ivanič and Camps 2001; Tang 2004; Lorés-Sanz 2011a,b; Hyland 2011) and, above all, in L2 writing research and pedagogy (Matsuda and Tardy 2007; Matsuda and Tardy 2008; Staplenton and Helms-Park 2008, John 2009, among others) and in particular in discourse analysis. Visibility may be thought of as being made up of different facets. Discourse analysts, have studied visibility through the dimensions of authority, credibility, academic identity, personality inter alia. Furthermore, it could be argued that in several corpus studies, as indicated in Hyland and Sancho (2012), the boundaries between voice and stance are still fuzzy and even ambiguous. Stance has generally been understood as a concept related to engagement. In Hyland's (1998: 20) words, stance should be related to "the way writers deploy community-sensitive linguistic resources to represent themselves, their position and their readers". Over the last few years, scholars have used different terms to refer to stance. While Biber and Finegan (1989) or Jaffe (2009) use the term stance, Hunston and Thompson (2000) use evaluation, and Goffman (1981) preferred the term footing, Hyland (1998) used the term hedging and Martin and White (2005) included stance under the umbrella concept of appraisal. Biber and Gray (2012) argue that stance is a continuum of evaluative meaning, which varies along two axes: one epistemic and interpersonal and the other linguistic. Therefore, stance has 
generally been approached in written discourse through the observation of selfmentions, boosters, hedges and adverbial markers of attitude. This study argues that there are conceptual blurred boundary lines, concretely between stance and voice, that should undoubtedly be established so to approach and interpret writers' voice and their consequent visibility. While scholarly disputes have tried to cast light onto this grey area (John 2005; Charles 2004, 2007; Tardy 2012; Hyland and Sancho 2012; Dressen-Hammouda 2014; Stock and Eik-Nes 2016) this study understands voice in Med-RAs as a tool to build objectivity and credibility. As introduced above, the effect created by the linguistic features associated with the notion of voice reveal what the writer seems to own: a process, ideas or knowledge (John 2005).

Therefore, this study which reflects on the notion of voice and how it is represented and measured in writing, is divided into four sections (Introduction, Corpus and methods, Results and discussion and Concluding remarks). The following sub-section (1.2) describes how the most frequent linguistic choices found, potentially associated to the notion of writers' voice in Med-RAs, have led this researcher to design a cline to interpret writers' visibility. It hereby explains how the combination of different frameworks of analysis (i.e. Martínez 2001; John 2005 and Hyland 2005) have been proved to be useful to interpret the writers' voice realizations in Med-RAs and these writers' consequent gradable (in)visibility. The following section (Corpus and methods), opens with the description of the corpus collection (2.1) and closes with the description of the data analysis (2.2). Section 3 focuses on the results found and discusses the findings related to the three most frequent lexico-grammatical choices found associated to writers' voice in Med-RAs. Finally, section 4 closes this study with some concluding remarks and future lines of research.

\subsection{Lexico-grammatical choices associated with the notion of voice}

To reflect on how the combination of different lexico-grammatical choices associated with the notion of voice affect the visibility of Med-RAs writers, the most frequent linguistic features will be interpreted in this study from the notion of writers' voice. Inspired by previous research on the aspects of authorial voice (Lorés-Sanz 2008; Bordet 2013), and supported by a pilot study of the corpus, Martínez' (2001) representation of participants in relation to congruence and negotiability was found to be of paramount importance to interpret data: 


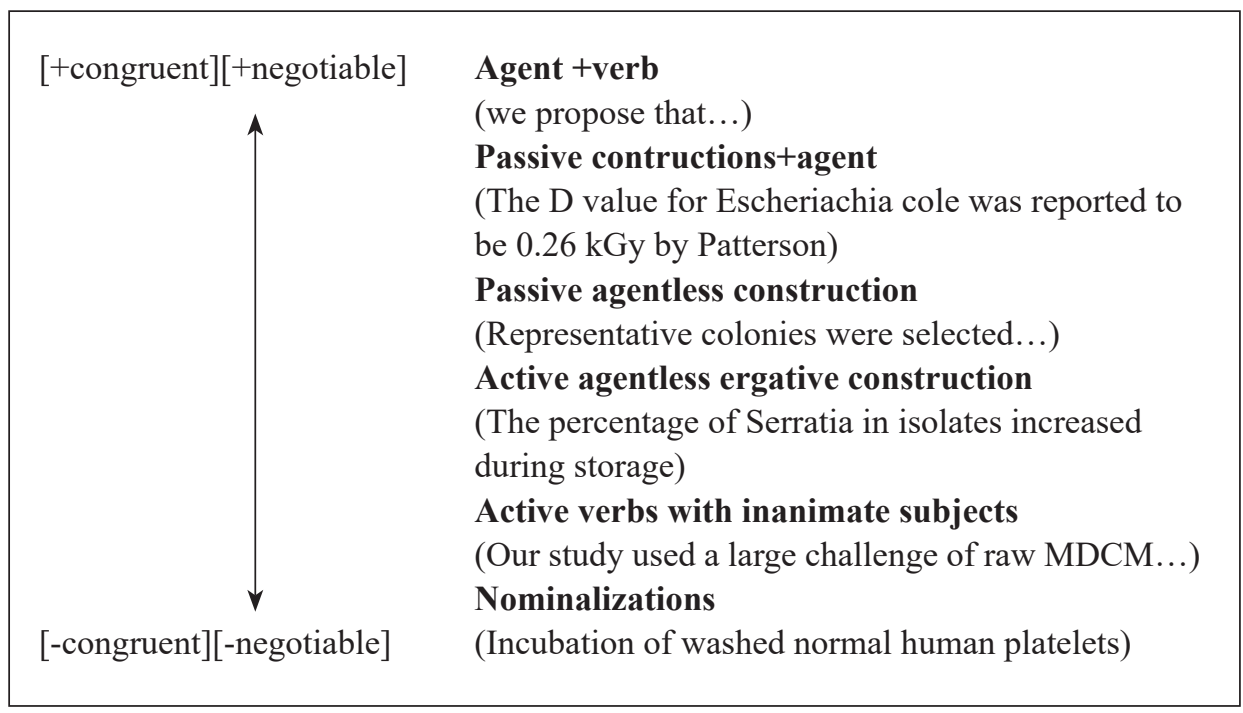

Figure 1. Adaptation of the figure proposed by Martínez (2001: 233) regarding the resources for the representation of participants in relation to congruence and negotiability.

In her cline of lexico-grammatical resources for the representation of participants - displayed above, Martínez associates the syntactic-semantic dimension with a pragmatic dimension of negotiability and non-negotiability. She adds: "The syntactic-semantic distance (Rutherford, 1987) that is created through the grammar is in inverse relation to congruence: the less congruent the construction, the more semantic distance between the surface representation and the meaning encoded." (2001: 234). Halliday and Martin (1993) noted that the interpersonal potential for negotiability is maximal when the agent is explicitly stated in the clause structure. Thus, the negotiability is minimal when the argument is encoded as a nominal construction.

Thus, Martínez's (2001) cline for the representation of participants and the ensued semantic relations was adapted (illustrated in Figure 1 above) in an attempt to measure and interpret the potential visibility associated to Med-RAs voice realisations: 


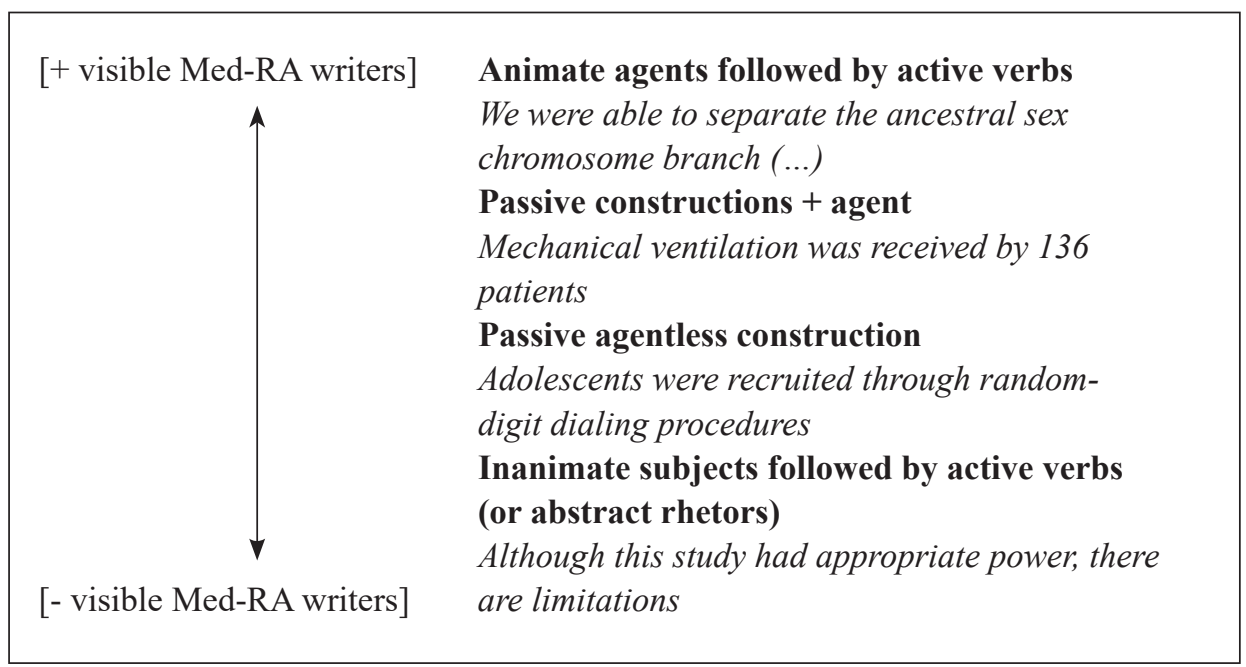

Figure 2. Cline of Med-RA writers' (in)visibility based on Martínez (2001: 233)

The formal features that are studied here, which portray the visibility of Med-RAs writers have been previously approached from traditional angles as Metadiscourse (Hyland 2005; Lorés-Sanz 2006, 2009; Mur-Dueñas 2007); Transitivy system (Halliday and Martin 1993, Martínez 2001, 2005) or rhetorical studies (Luzón-Marco 2000; Vande Kopple 2002) among others. Results will be observed regarding the highly conventionalised structure of medical Med-RAs published in international journals. Hence, the authors are expected to be visible throughout the Med-RAs by means - among other lexico-grammatical features - of the following linguistic manifestations: the first person plural pronoun we, the object pronoun $u s$ and the possessive adjective our. Inspired by Tang and John (1999), studies such as Harwood (2005 a,b), considered the use of personal pronouns is not merely a grammatical choice but a choice that has sociolinguistic consideration.

In the same vein, the second linguistic choice that is directly associated with the writers' presence, their voice and therefore their visibility is the use of the passive voice. Passive constructions are a well-known representative feature of the RA genre that has been studied from different angles: from personal and impersonal authorial reference (Molino 2010), from the potential authorial involvement in science popularizations (Kim and Thompson 2010), as collocational frameworks in medical RAs (Luzón-Marco 2000), or from the point of view of writers' stance and their knowledge, responsibility and commitment (Hyland 2005), among others. Overall, passive constructions show the RA writer's detachment from what is being conveyed as regards the implications or responsibility of the research. In the RA genre, passive constructions are one of the most distinctive rhetorical conventions as many scholars such as Biber and Finegan (1989) and Swales and Feak (2004), have pointed out. An additional observation could be added regarding what type of research process or verbal act follow the passive subjects in the agentless passive constructions. That is, the exploration of the verbal phrases in 
passive constructions confirms whose research experience, and therefore whose visibility, is being portrayed since the semantic implication of the verbs chosen confirms that the Med-RAs researchers conducted the scientific process.

The lexico-grammatical feature that follows the axe of the authorial visibility in this analysis is the inanimate subject or abstract rhetor. To justify the foundation of the analysis of inanimate subjects followed by active verbs, we should turn to the theoretical scaffolding of Rhetorical Attenuation and the System of Transitivity in order to interpret the results obtained from the study of the authorial visibility. It seems unquestionable that one of the characteristics of scientific discourse is the persistent use of rhetorical conventions. Many researches (Prince et al. 1982; Salager-Meyer 1994; Hyland 1998; Varttala 1999 and Fortanet et al. 2001) have studied the need to use rhetorical features in medical discourse to introduce explicit authorial distance.

Drawn from previous studies based on the rhetorical conventions in English, a syntactical approach is taken here to observe how and why Med-RAs authors depersonalise their own texts. The linguistic items under study, which help us observe how authors hide their attitude towards the content (Lewin 1998) and how authors fulfil academic conventions to seem more precise and more scientific (Salager-Meyer et al. 2003), are agentless passive structures and nominalisations. For the purposes of the study I think the analysis of abstract rhetors can be more profitable than the study of nominalisations (Halliday 1994). In agreement with Hyland (1998), Luzón-Marco (2000) and Ferrari (2003), I understand that abstract rhetors nominalise a personal projection and suggest that the situation described is independent of human agency. Therefore, the use of abstract rhetors contributes to the depersonalisation of discourse, displaying the implications of the medical study as the source of any epistemic judgement.

\section{Corpus and methods}

\subsection{Corpus collection}

An ethnographic approach was taken to compile the corpus of the study so as to facilitate the comprehension of the medical academic literacy practices allowing this researcher to depart from context, turning to the texts and going back to context (Lillis 2017). A survey-based study was conducted among 110 practitioners from different specialities in the two University hospitals (Hospital Clínico Universitario Lozano Blesa and Hospital Universitario Miguel Servet) both from Zaragoza (Spain). The survey belonged to a broader investigation which explores practitioners' literary practices. Only questionnaires from doctors who had a double position as University teachers at the Faculty of Medicine and as clinical personnel at their hospitals (researchers, teachers and practitioners) were chosen. Participants were asked which research journal they read most frequently. From their answers to the question related to the most consulted medical journal, 
I accessed the 28 specialised medical journals participants said to read monthly and, then, 40 articles were selected (see Appendix). I chose Med-RAs which were easier to comprehend since I aimed to carefully trace the potential lexico-grammatical features associated to the writers' voice. To do so, no computer tools were used and thus the corpus was scanned manually. The journals had a high impact factor classified in the first quartile of their category (Q1) and the Med-RAs that constitute the corpus were published in 2009 October's volume.

The corpus of Med-RAs amounts to a total of 182,065 words. The average number of words per articles is 4,452, once abstracts, footnotes, acknowledgements and bibliography were removed. Small sample yet illustrative to conduct my exploratory data-driven study and seek the most frequent linguistic choices associated with the writer's voice.

Med-RAs included in the corpus display a conventionalised structure based on moves. This structure includes the following moves: Introduction, Methods (and Patients), Results and Discussion. All the Med-RAs selected in the corpus were co-authored and all of the researchers were mentioned by name. Some of the articles studied have been written by non-Anglophone scholars although all of them were published in prestigious American and British journals (see http:// www.scimagojr.com/journalsearch.php) and therefore were considered convenient texts to be studied. This exploratory attempt to work with ethnographic data might allow applied linguists to work with production processes and not reified texts and also to critically re-visit assumptions about language use, texts and genres (Lillis 2017).

\subsection{Analysis of data}

The linguistic choices potentially associated to writer's voice have been studied in isolation by manual reading. I turned to Martínez (2001) study on impersonality so as to relate the different voice realisations Med-RAs writers make to modulate their (in)visibility. Her approach inspired the idea of grading in a cline the lexico-grammatical realizations of the writers' voice since these writers are expected to project their visibility appropriately seeking for a balance to suit the genre expectations. This idea, together with the manually scanned data, revealed that the study of the most recurrent features associated with the writers' voice should adopt different frameworks of interpretation.

Hence, the most frequent voice realisations in Med-RAs were approached from different angles: 1) Animate subjects agents followed by active verbs 2) Passive constructions and 3) Inanimate subjects followed by active verbs or abstract rhetors. Cases of reporting verbs and citations were also recurrent yet not as frequent as the tokens studied here although they could be the object of study for future research (Shaw 1992; Thomas and Hawes 1994; Fortanet-Gómez 1998, among others).

Additional research could have been carried out looking at the type of research process or the verbal acts that followed these lexico-grammatical choices. Nonetheless, the verbal acts chosen by these writers were left out of the study since 
they all confirmed the role of these researchers as actors and agents of the medical research, and therefore, ratify the authorial identity and presence on the Med-RAs researchers. That is, drawing from Downing and Locke's (2002) approach on how to express patterns of experiences, it should be noticed that all the verbal processes found were verbs that made reference to (i) material processes or processes of "doing" and "causing" and (ii) cognition or mental processes and only Med-RAs researchers are responsible from them as the following examples illustrate:

(1) We identified 4,639 patients who underwent Roux-en-Y gastric bypass surgery and a control group of 4,639 obese patients who did not have surgery in a national private insurance claims database in a 5-year period (2002 to 2006). [Med-RA19]

(2) A total of 21,161 people of all ages took part in the NHANES from 2001 through 2004; 6785 participants (32.1\%) were aged 40 years and older. Participants were excluded from balance testing if they were unable to stand on their own, were having dizziness sufficient to cause unsteadiness, weighed more than 275 pounds, (...) [Med-RA4]

(3) Our study did not show any associations between exposure to viral nucleic acids and SGA, despite other research suggesting possible links.

[Med-RA1]

As for inanimate subjects followed by active verbs or abstract rhetors, inspired by previous studies (Bondi 2009), the formal analysis in this paper has been based on the study of the following abstract rhetors: study, results, findings, analysis and research. This choice is supported by previous literature (Herrando-Rodrigo 2010).

\section{Results and discussion}

This section displays the findings related to the most frequent writer's choices associated with the projection of their voice in Med-RAs and the different frameworks of analysis used to grade the resulting visibility. Section 3.1 opens with the discussion of some morphological units that are used to represent the authors in Med-RAs (such as the use of personal pronouns, object pronouns or possessive adjectives). Section 3.2 deals with the exploration of the results obtained in the analysis of the most frequent alternatives to the use of animate agents followed by active verbs, that is, passive constructions. Section 3.3 discusses the use of inanimate subjects followed by active verbs, or abstract rhetors, as a devoicing mechanism in Med-RAs. Finally, section 3.4 closes this Results and Discussion section with some final remarks. Table 1 below summarises the lexico-grammatical features studied and their frequency: 
Table 1. Lexico-grammatical features studied. Total number of tokens and normalised results per 1,000 words

\begin{tabular}{|l|c|c|}
\hline \multirow{2}{*}{ Variables studied } & \multicolumn{2}{|c|}{ Med-RAs } \\
\cline { 2 - 3 } & Total number of tokens & Normalised results per 1,000 \\
\hline $\begin{array}{l}\text { Animate agents fol- } \\
\text { lowed by active verbs }\end{array}$ & 1,165 & 6.39 \\
\hline Passive Constructions & 2,912 & 15.99 \\
\hline $\begin{array}{l}\text { Inanimate subjects fol- } \\
\text { lowed by active verbs } \\
\text { (or abstract rhetors) }\end{array}$ & 327 & 1.79 \\
\hline
\end{tabular}

\subsection{Animate agents followed by active verbs}

In my Med-RAs corpus, researchers claim the authorship of their work and the ownership of their findings using self-mentions as exemplified below. Only exclusive pronouns were considered in my analysis since they exclude from these self-mentions every participant who is not a member of the research team. Moreover, only plural forms were found since all the Med-RAs were co-authored:

(4) Similarly to our previous findings, in this different AD population we observe that higher adherence to the MeDi is associated with reduced disease odds. Similarly to our previous report, we note a gradual reduction in $\mathrm{AD}$ risk for higher tertiles of MeDi adherence, suggesting a possible dose-response effect. [Med-RA16]

The tokens found represent the authorial voice of the researchers - making their presence more visible in the texts - by means of the three morphological units under study:

Table 2. Use of pronouns as authorial markers. Total number of tokens and normalised results per 1,000 words

\begin{tabular}{|c|c|c|c|c|c|c|}
\hline \multicolumn{2}{|c|}{ we } & \multicolumn{2}{c|}{ us } & \multicolumn{2}{c|}{ our } & Total \\
\hline 763 & 4.9 & 12 & 0.06 & 390 & 2.14 & $1,165(6.39)$ \\
\hline
\end{tabular}

These results show that the use of the first person plural pronoun we and the possessive adjective our are the most common authorial devices whereas the frequency of object pronoun $u s$ is very low:

(5) We observed that immediately following suppression of recombination between A and Y, likely due to their importance in both sexes, X gametologs largely maintained the ancestral autosomal sequence and functional constrains. [Med-RA30] 
The 763 tokens of the plural pronoun we were recorded in 38 of the articles comprising the Med-RAs corpus. Two Med-RAs showed no instances of the first person plural subject pronoun we or the possessive adjective our for that matter (Med-RA11 and Med-RA13):

(6) Our population of patients undergoing cardiothoracic surgery was markedly different form those of prior studies investigating the relationship between PFO and stroke. [Med-RA24]

Only 12 tokens of the object pronoun $u s$ were recorded. This low figure ( 0.06 per 1000 words) points towards the fact that Med-RAs writers favour the use of other realisations, which affects the degree of visibility in their texts - that is, the use of we and our. Moreover, the fact that the 6 instances were found in Med-RA30 may also reveal idiosyncrasies and stylistic choices on the part of the writers:

(7) The anastomatic time represented a more objective measurement of the degree of difficulty, allowing us to more directly compare the three techniques. [Med-RA6]

As for the use of our, no instances of this possessive adjective were found in Med-RA11. However, 39 Med-RAs did include instances of our. In other words, almost all of the Med-RAs share the use of this authorial device to make writers visible in Med-RAs:

(8) Finally, as with all observational studies, our data do not allow us to infer the direction of causality between negative religious coping and well-being. [Med-RA31]

In all, the frequency of use of both we and our is remarkable in the corpus under study. These results indicate that most of the Med-RAs researchers project their authorship and visibility in their RAs by means of personal pronouns and the possessive adjective. It could be inferred that Med-RAs researchers prefer the use of these morphological units with the syntactic function of subject or premodifier of a noun phrase, which explicitly show the agency of the research.

\subsection{Passive constructions}

It is agreed that in English for Academic Purposes (EAP) the rhetorical intention of passive constructions is to emphasise the entities studied or the research process presented in the RAs and not the authorship of the research. Passive constructions are then essential rhetorical lexico-grammatical tools to convey impersonality and therefore needed by RAs writers to suit the genre expectations in the academia. Table 3 below illustrates the results found regarding Passive Constructions: 
Table 3. Passive constructions Med-RAs. Total number of tokens and normalised results per 1,000 words

\begin{tabular}{|l|c|c|}
\hline \multirow{2}{*}{} & \multicolumn{2}{|c|}{ Med-RAs } \\
\cline { 2 - 3 } & Total number of tokens & Normalised results per 1,000 \\
\hline Passive Constructions & 2,912 & $(15.99)$ \\
\hline
\end{tabular}

Hence, turning to the formal analysis of data it can be said that it was therefore not unexpected that as many as 2,912 tokens ( 15.99 per 1,000 words) of agentless passive constructions were found in Med-RAs. See for example:

(9) Blood sampling for the study was done during routine blood workup. [Med- RA28]

These passive constructions show the highest frequency of all the variables suggested by the formal analysis of the Med-RAs corpus contributing to the widely accepted assumption that RAs contents cannot be presented at random as regards syntactic structures or lexico-grammatical features. In other words, to fit in the genre and in its context, RAs must strictly follow the rhetorical conventions characteristic of the field of publication. Therefore, the use of the passive in RAs is not a question of the authors' proximity to certain rhetorical backgrounds but a genre specific convention as has earlier been pointed out in this section. Therefore, it is not surprising that every Med-RA presented instances of passive constructions. Med-RA15 in the corpus under study presented the highest frequency with 152 tokens and Med-RA36 represented the lowest frequency with 10 tokens found. Unfortunately, this author cannot bluntly state whether the different frequencies respond to the researchers' commitment with medical content or just to idiosyncratic stylistic choices.

Researchers wish to highlight what was done, and not who did it, in order to present the research procedures as an objective, meticulous, professional and aseptic process. The agent of these agentless passive constructions used in RAs is never explicitly written but easily deduced as shown in the examples below $(10,11)$. These examples have been modified and the potential agents have been introduced to exemplify what has just been explained. The communicative intention of the resulting impersonality conveyed by agentless passive constructions may be to avoid responsibility for what is being conveyed or also to present the research as a trustworthy entity with no human intervention:

(10) Adolescents were recruited (by the researchers) through random-digit dialing procedures, followed by mailing of recruitment packets. [MedRA33]

(11) Optimal Pegylated Interferon Therapy (IDEAL) study was initiated (by the researchers) to compare standard-dose and low-dose regi- 
mens of peginterferon alfa- $2 \mathrm{~b}$, plus ribavirin, after it was observed (by the researchers) that both dose levels yielded similar rates of sustained virologic response in the absence of ribavirin. [Med-RA37]

In the Med-RAs corpus there were passive constructions with an explicit agent. Nonetheless, these constructions neither refer to the authorship of the Med-RAs nor give researchers visibility as can be observed in the following example:

(12) Mechanical ventilation was received by 136 patients $(81.0 \%)$

[Med-RA40]

Therefore, Med-RAs researchers choose to use agentless passive constructions to suit the genre linguistic conventions - to seek objectivity, to hide the researchers' stance or to avoid commitment or responsibility towards the scientific findings. Thus, Med-RAs writers' tendency to avoid passive constructions with agent or active structures should be considered as one of the most powerful devoicing mechanisms. Explaining, for instance, in the Methodology sections who carried out the procedures with active voice structures should unveil who did what and also it should contribute to clarify the medical content as paraphrased examples $13(\mathrm{a}, \mathrm{b})$ aim to display:

\begin{tabular}{|l|l|}
\hline \multicolumn{1}{|c|}{ Examples found } & \multicolumn{1}{|c|}{ Potentially paraphrased example } \\
\hline $\begin{array}{l}\text { (13.a) Laboratory technicians were blind- } \\
\text { ed to all food labeling information. All } \\
\text { samples were ground before analysis. Po- } \\
\text { tassium was measured using the Associa- } \\
\text { tion of Analytical Communities (AOAC) } \\
\text { thors of the research) measured Potassium } \\
\text { official method 985.01. Phosphorus was } \\
\text { measured using AOAC official method } \\
\text { monities (AOAC) official method 985.01; } \\
\text { instead of "Potassium was measured using } \\
\text { rus assays are inductively coupled plasma } \\
\text { the Association of Analytical Communities } \\
\text { [Med- RA34] }\end{array}$ & \\
\hline \multicolumn{2}{|l}{ [MAC) official method 985.01" } \\
\hline
\end{tabular}

Results show that writers' degree of visibility resulting from these rhetorical choices should be in line with the expectations of their discourse community. Besides, this highly conventionalised feature mediates, veils and therefore grades, these writers' visibility to a lesser extent as in general this work suggests and Figure 2 above, in particular, summarizes.

\subsection{Inanimate subjects followed by active verbs or abstract rhetors}

In the formal analysis of Med-RAs 327 tokens (1.79 per 1,000 words) of abstract rhetors were found. The occurrence of abstract rhetors in my Med-RAs corpus is 
not very high if this figure is compared to the other variables under study. Table 4 summarises the results found:

Table 4. Use of abstract rhetors in Med-RAs. Total number of tokens, normalised results per 1,000 words and the representing percentage from the total amount of abstract rhetors in the Med-RAs corpus

\begin{tabular}{|c|c|c|c|c|c|}
\hline Study & Results & Findings & Analysis & Research & Total \\
\hline $144(0.79)$ & $88(0.48)$ & $65(0.35)$ & $25(0.13)$ & $5(0.02)$ & $327(1.79)$ \\
$44.03 \%$ & $26.9 \%$ & $19.8 \%$ & $7.6 \%$ & $1.5 \%$ & $100 \%$ \\
\hline
\end{tabular}

Although reference is made to the overall number of abstract rhetors, it may be useful to observe that the most recurrent and representative abstract rhetor in this corpus is study -see example 10 below. Unfortunately, this study cannot state the rationale behind this frequency. Example 10 example is introduced below:

(14) Our study also included more heavily pretreated subjects than most previously reported studies. [Med-RA9]

Despite the high occurrence of this abstract rhetor, 10 Med-RAs did not show any instance of study. ${ }^{1}$ This unbalanced distribution may lie in the idiosyncrasies and stylistic choices that writers seem to make although the use of abstract rhetors in medical academic writing could be considered a generic convention rather than a writers' linguistic choice. For instance, in the Med-RAs corpus we can find one text (Med-RA17) with 23 tokens of study and four others (Med-RA1, Med-RA2, Med-RA3 and Med-RA5) with more than 10 tokens of study each.

Results is the second most frequent abstract rhetor in my Med-RAs corpus. Eighty-eight tokens ( 0.48 per 1,000 words) were found. I include the following examples to illustrate this:

(15) The results require confirmation but are of potential concern, because IQ is an important predictor of subsequent academic performance.

[Med-RA32]

(16) The results of the repeated measures analysis supported the findings of the analyses using baseline values for glucose, insulin and HOMA-IR.

[Med-RA35]

Fourteen Med-RAs did not show any token of the use of results. This is not surprising due to the lower occurrence of this abstract rhetor in my corpus. Nine Med-RAs have an occurrence of 4 or more and three RAs (Med-RA1, Med-RA3 and Med-RA 36 present) 6 or more tokens of results.

Sixty-five tokens ( 0.35 per 1,000 words) of the abstract rhetor findings were found. 
Seventeen Med-RAs used this abstract rhetor:

(17) Therefore, our findings demonstrate the need to investigate loss of menstrual cycle regularity in a timely manner. [Med-RA22]

(18) These findings clarify prior research in two ways. First, limitations of prior research were overcome in the current study by the use of standardized diagnostic measures to assign group membership. [Med-RA29]

The distribution of the tokens among the Med-RAs is again uneven. Five MedRAs (Med-RA1, Med-RA2, Med-RA11, Med-RA14 and Med-RA17) presented 8 or more tokens of this abstract rhetor. Analysis and research are less frequent than the other abstract rhetors under study. Twelve Med-RAs show tokens of analysis and just 3 Med-RAs use the abstract rhetor research. Some examples have been included below:

(19) This analysis adds to the growing number of condom analyses that use an absolute number of unprotected sex acts for exposure as opposed to the more traditional measure of percentage condom use. [Med-RA25]

(20) Future research should investigate the mechanism(s) responsible for the effects of excess abdominal fat distribution on the relationship between PM2.5 and BP measures. [Med-RA39]

The meaningfulness of plural and singular abstract rhetors could be evaluated. That is, study and studies, result and results or finding and findings. A peculiarity should be mentioned here. The only remarkable feature of using the abstract rhetors in their plural or singular form was found in the distinction made between the singular study and the plural studies. When Med-RAs authors used the singular form, they were usually making reference to their Med-RA. Nonetheless, when the plural form was used, a reference to previous literature was established most of the times in the introduction or background move. Something semantically similar takes place with the abstract rhetor research. The 5 tokens found refer to previous research or future research still to be done. An example is quoted to illustrate this reflection:

(21) However, recent genome- wide association studies have also indicated that most common genetic risks, at least when studied individually, are modest in magnitude, with relative risks in the range of 1.3 or less.

[Med-RA17]

With Luzón-Marco (2000) and her interpretation of abstract rhetors in Med-RAs - based on Halliday's (1998) approach to active verbs with inanimate subjects - the results discussed in this section should be interpreted as a Med-RAs ge- 
neric convention of presenting the implications of the medical study. Therefore, as Hyland (1998) also points out, the situation described in the Med-RAs is independent of human agency. This alternative to the use of the passive construction as a depersonalisation strategy contributes, according to Ferrari (2003), to the depersonalisation of medical discourse by obtaining data as the source of any epistemic judgement.

\subsection{Some final remarks}

Despite the idiosyncrasies revealed by the data and potential stylistic choices - such as that Med-RA15 presented the highest frequency of passive constructions (152 tokens) and a low frequency of self-mentions ( 2 tokens), Med-RA36 represented a low frequency of passive constructions (10 tokens) and a high frequency of selfmentions (21 tokens) or Med-RA11 and Med-RA13 presenting no self-mentions tokens - the quantitative approach to these results showed that Med-RAs writers tend to favour the use of passive constructions when making themselves visible in their articles (2,912 tokens). The cline designed for this study portrayed selfmentions as the most obvious representation of the Med-RAs writers' presence. In the corpus 1,165 tokens were found. Nonetheless, it is not surprising that the frequency of passive constructions in the corpus doubled in use that visibility choice $(2,912$ tokens). It should then be noted that Med-RAs writers under study project a veiled (in)visibility associated to passive constructions.

Abstract rhetors presented the lowest frequency (327 tokens) yet, they directly were interpreted as Med-RAs results and products. Contrastive studies dealing with (im)personality and (de)personalisation processes have been conducted in RAs and in scientific dissemination articles by Ciapuscio (2003), Ferrari and Gallardo (1999), Gil-Salom (2000) or Martínez (2001). They suggest that nominalisations and, more specifically, abstract rhetors are kept in the resulting scientific dissemination articles or popularizations to maintain the reader's trust in the research process.

The representation of the different visibility choices which help Med-RAs writers to modulate their voices and presence studied here, aids to craft writers' visibility and construct their research credibility meeting the expectations of Med-RAs genre, their readers and overall, of their discipline.

\section{Concluding remarks}

This study aimed at reflecting on the notion of writers' voice - understood as the indicator of the writers' presence in their text - and investigating how this voice can uncover the extent of writers' (in)visibility in medical academic research papers published in high-impact journals. A cline has been proposed to measure, and further interpret, writers' (in)visibility.

The analysis reveals that what this study understands as writers' voice can be measured, and more concretely, it can be associated to writers' presence. Animate 
agents followed by active verbs, passive constructions and inanimate subjects followed by active verbs or abstract rhetors have proved to be the most recurrent lexico-grammatical features associated with the writers' voice in Med-RAs. Whereas writers of academic texts claim the authorship of their work using selfmentions (Hyland 2005, 2018a; Lorés-Sanz 2006, 2009; Mur-Dueñas 2007; MurDueñas and Šinkūnienè 2016) as the most powerful voicing mechanism, they also use passive constructions and abstract rhetors in an attempt to emphasise the research process rather that the writers' agency (Luzón-Marco 2000; Martínez 2001, 2005; Vande Kopple 2002). These devoicing mechanisms allow writers to be less visible as we move down the axe of this study's cline of visibility (see Figure 2 in section 1.2), yet never absent from their texts. Nevertheless, in this Med-RAs corpus in particular, the uses of passive constructions outnumber those of self-mentions. As previous research shows (Seoane and Hundt 2018), passive constructions are indispensable to create objective knowledge, apparently deprived of human intervention, in academic writing in general and in medical discourse in particular. Despite the voice alternation in genres and disciplines, it is easy to unveil the agency of the research experience reported by the apparent impersonal construction of a passive structure. In sum, the apparent blurred (in) visibility is permanently unveiled with the (de)voicing mechanism under study that allows us to move up and down the cline of visibility for its interpretation and that must always meet both the discipline and genre expectations (Swales and Feak 2004; Matsuda and Tardy 2007). Different audiences may construct their voice and therefore craft their visibility in distinct ways. Largely, the use of the lexico-grammatical features, identified as markers of (in)visibility, makes the reader identify and interpret the voice of a writer as potentially dormant. All in all, results suggest that we should go beyond some models and traditional frameworks of discourse analysis since there is a risk of overestimating some linguistic features such as first person pronoun and we may ignore content-related features that might be relevant in the construction of voice as Stock and Eik Nes (2016) contend.

This paper also claims for a strategic authorial presence in academic discourse taking into consideration our disciplinary voice and genre expectations. Thus, writers should be able to grade their (in)visibility to fit discourse practice expectations and therefore construct credibility. It is highly important for writers, members of given discourse communities, to acknowledge how that voice could be constrained by their discipline (Dressen-Hammouda 2014) and academic genre in use (Dressen-Hammouda 2008) since how we craft and project our disciplinary voice will make what we say trustworthy (Herrando-Rodrigo 2014).

Since the study was limited to 'unpack' the concept of authors' visibility in Med-RAs by analysing one of the dimensions that conforms this concept, that is the writers' voice, it was not possible to identify further linguistic features associated with the notion of writers' voice in the corpus.

Overall, this study suggests that we should all be aware of the notion of voice, its implications and the values associated with our resulting visibility in any 
discourse practice. Although future lines of research such as investigating the discipline-specific voicing and devoicing mechanisms in each section of MedRAs and even distinguishing whether visibility varies among different medical specialties and academic disciplines, further pedagogical implications for EAP writing instruction ensue from this study as Swales (1997), Curry and Lillis (2004) and Tardy (2004) also suggested in their studies. These findings could inform discipline-specific guidelines and resources (Hyland 2018b). Such materials should make writers aware of the importance of tuning their degree of visibility in their academic papers. In addition, writing instructors, teachers, language mediators and curriculum developers should concern about raising their trainees' and students' awareness about the importance of modulating their voice accordingly in written texts (Herrando-Rodrigo Mur-Dueñas and Lorés-Sanz 2012; Laso and John 2017). In doing so, learners should become aware of the implications, risks and dangers of maintaining (or going against) generic conventions used in a specific genre and disciplinary context.

\section{Note}

Med-RA2, Med-RA8, Med-RA22, Med-RA23, Med-RA24, Med-RA25, Med-RA30, MedRA34, Med-RA38 and Med-RA39.

\section{Acknowledgement}

This research has been supported by the Spanish Ministerio de Economía, Industria y Competitividad (FFI2017-84205-R), "the Gobierno de Aragon CIRES (H16-17-R)" and by the Fundación Ibercaja together with the University of Zaragoza (JIUZ-2018-HUM-03). The author would also like to thank Dr. Pilar Mur-Dueñas and Dr. Rosa Lorés-Sanz (University of Zaragoza, Spain), and Dr. Suganthi John (University of Birmingham, UK) for their insightful comments on this paper.

\section{References}

Biber, Douglas and Eduard Finegan (1989) Style of stance in English: lexical and grammatical marking of evidentially and affect. Text 9 (1), 93-124.

Biber, Douglas and Bethany Gray (2012) Current conceptions of stance. In: Ken Hyland and Carmen Sancho-Guinda. (eds.) Stance and Voice in Academic Genres. Basingstoke: Palgrave Macmillan, 15-34.

Bondi, Marina (2009) Polyphony in academic discourse: A cross-cultural perspective on historical discourse. In: Sumela-Salmi, Eija and Dervin, Fred (eds.) Cross-linguistic and Cross-cultural Perspective on Academic Discourse. Amsterdam: John Benjamins, 83-108.

Bordet, Ganvier (2013) The rhetorical role of 'collocational chains' and their implications in the building of scientific discourse strategies. European Journal of English Studies 17 (3), 235-250. 
Bowden, Darsie (1995) The rise of a metaphor: voice in composition pedagogy. Rhetoric Review 14 (1), 173-188.

Burgess, Amy and Ivanič, Roz (2010) Writing and being written. Issues of identity across timescales. Written Communication 27 (2), 228-255.

Butler, Judith (1990) Gender Trouble: Feminism and the Subversion of the Identity. London: Routledge.

Charles, Maggie (1999) Aspects of the author's voice in three academic research articles. In: Thompson, Paul (ed.) Issues in EAP Writing Research and Instruction. CALS publication, 71-83.

Charles, Maggie (2004) The construction of stance: a corpus-based investigation of two contrasting disciplines. University of Birmingham. PhD Thesis. (Unpublished).

Charles, Maggie (2006) Revealing and obscuring the writer's identity: evidence from a corpus of theses. In: Kiely, R., Rea-Dikins, P., Woodfiled, H. and Clibbon, G (eds.), Language, culture and identity in applied linguistics British Studies in Applied Linguistics 21, 147-161.

Charles, Maggie (2007) Argument or evidence? Disciplinary variations in the use of the Noun that patter in stance constructions. English for Specific Purposes 23, 203-218.

Ciapuscio, Guimar (2003) Formulation and reformulation procedures in verbal interactions between experts and (semi-)laypersons. Discourse Studies 5 (2), 207-233.

Curry, Mary Jane and Theresa Lillis (2004) Multilingual scholars and the imperative to publish in English: Negotiating interests, demands and rewards. TESOL Quarterly 38(4), 663-688.

Dressen-Hammouda, Dacia (2008) From novice to disciplinary expert: Disciplinary becoming and genre mastery. English for Specific Purposes 27, 233-252.

Dressen-Hammouda, Dacia (2014) Measuring the voice of disciplinarity in scientific writing: A longitudinal exploration of experienced writers in geology. English for Specific Purposes 34, $14-25$.

Downing, Angela and Philip Locke (1992) 2002 A University Course in English Grammar. London: Routledge.

Elbow, Peter (1994) What do we mean when we talk about voice in texts?. In: Blake Yancey, K. (ed.) Voices on Voice: Perspectives, Definitions, Inquiry. Illinois: National Council of Teachers of English, 1-35.

Fairclough, Norman (1992). Discourse and Social Change. Cambridge: Polity Press.

Fairclough, Norman (1995). Critical Discourse Analysis. Harlow: Longman.

Ferrari, Laura and Susana Gallardo (1999) Los marcadores de evindecialidad empleados por la prensa en una controversia ambiental. Discurso y Sociedad. Barcelona. Gedisa 1(4), 69-93.

Ferrari, Laura (2003) Marcadores de modalidad epistémica en artículos de investigación”. In: García Wegroni, Marta (ed.) Actas del Congreso Internacional La Argumentación. Buenos Aires: Instituto de Lingüística.

Fortanet, Inmaculada (1998) Verb usage in academic writing: Reporting verbs in economics research articles in English and in Spanish. In: Lita Lundquist, Heribert Picht and Jacques Qvistgaard (eds.) Proceedings of the $11^{\text {th }}$ European Symposium on Language for Special Purposes. LSP Identity and Interface Research, Knowledge and Society. Copenhagen: Copenhagen Business School, LSP Centre, 231-240.

Fortanet, Inmaculada, Palmer, Juan Carlos and Posteguillo, Santiago (2001) Hedging devices in technical and academic English. In: Palmer, Jose Carlos, Posteguillo, Santiago and Fortanet, Inmaculada (eds.) Discourse Analysis and Terminology in Language for Specific Purposes. Castelló: Universitat Jaume I, 13-24.

Foucault, Michel (1972) The Archaeology of Knowledge. London: Tavistock.

Gil-Salom, Luz (2000-2001) El discurso de la ciencia y la tecnología: El artículo científico de investigación vs. el artículo de divulgación científica. RESLA 14, 429-449.

Goffman, Erving (1981) Forms of Talk. Oxford: Oxford University Press.

Halliday, Michael A. K. (1994) An Introduction to Functional Grammar. London: Arnold.

Halliday, Michael A. K. (1998) Things and relations: regrammaticising experience as technical knowledge. In: Martin, James and Veels, Robert (eds.) Reading Science. London: Routledge, $185-235$. 
Halliday, Michael A. K. and Martin, James (1993) Writing Science: Literacy and Discursive Power. London: Falmer Press.

Harwood, Nigel (2005a) 'Nowhere has anyone attempted... In this article I aim to do just that': A corpus-based study of self-promotional $I$ and we in academic writing across four disciplines. Journal of Pragmatics 37, 1207-1231.

Harwood, Nigel (2005b) 'We do not seem to have a theory ... the theory I present here attempts to fill this gap': Inclusive and exclusive pronouns in academic writing. Applied Linguistics 26 (3), 343-375.

Herrando-Rodrigo, Isabel (2010) 'If you suffer from... Check the Internet': The role of self mentions and engagement markers in medical research articles and electronic popularizations. In: Lorés-Sanz, Rosa, Mur-Dueñas, Pilar and Lafuente-Millán, Eenrique (eds.) Constructing Interpersonality: Multiple Perspectives on Written Academic Genres. Cambridge: Cambridge Scholars Publishing, 255-275.

Herrando-Rodrigo, Isabel (2014) A Contribution to the Study of Writers' Self-representation: Visible Researchers, Invisible Writers, or How to Make Medical Electronic Popularizations Trustworthy. Zaragoza: Prensas Universitarias Zaragoza.

Herrando-Rodrigo, Isabel, Mur-Dueñas, Pilar and Lorés-Sanz, Rosa (2012) Academic Writing in Health Science. Zaragoza: Prensas Universitarias Zaragoza.

Hunston, Susan and Thompson, Geoff (2000) Evaluation in Text: Authorial Stance and the Construction of Discourse. Oxford: Oxford University Press, 1-27.

Hyland, Ken (1998) Hedging in Scientific Research Articles. Amsterdam: John Benjamins.

Hyland, Ken (2005) Stance and engagement: a model of interaction in academic discourse. Discourse Studies 7 (2), 173-192.

Hyland, Ken (2015). Genre, discipline and identity. Journal of English for Academic Purposes. 19, 32-43.

Hyland, Ken (2018a) Narrative, identity in academic story telling. ILCEA 38, 1-16.

Hyland, Ken (2018b) The communication of expertise: Changes in academic writing over 50 years. CERLIS 2018. Università di Bergamo (Italy). 21-23 June, 2018.

Hyland, Ken and Sancho, Carmen (2012) Stance and voice in Academic Discourse. Basingstoke: Palgrave Macmillan.

Ivanič, Roz (1998) Writing an identity: the discoursal construction of identity in academic writing. Amsterdam: John Benjamins Publishing Company.

Ivanič, Roz and Camps, David (2001) I am how I sound: voice as self representation in L2 writing. Journal of Second Language Writing 10, 3-33.

Jaffe, Alexandra (2009) Stance: Sociolinguistic Perspectives. Oxford: Oxford University Press.

John, Suganthi (2005) The Writing Process and Writing Identity: Investigating the Influence of Revision on Linguistic and Textual Features of Writer Identity in Dissertations. UK: University of Birmingham. PhD Thesis (Unpublished).

John, Suganthi (2007) Meeting the challenge of developing an academic identity a textual approach. In: Teo, P and Ho, C. (eds.), Discourse in the modern world: Perspectives and challenges. Singapore: McGraw-Hill, 28-52.

John, Suganthi (2009) Using the revision process to help international students understand the linguistic construction of the academic identity. In: Charles, Maggie, Diane, Pecorari and Susan Hunston (eds.) Academic Writing: At the Interface of Corpus and Discourse. London: Continuum, 272-290.

Kim, Chul-Kyu and Thompson, Geoff (2010) Obligation and reader involvement in English and Korean science popularizations a corpus-based cross-cultural text analysis. Text \& Talk 1, 53-73.

Laso, Natalia and John, Suganthi (2017) A corpus-based analysis of the collocational patterning of adjectives with abstract nouns in medical English. $9^{\text {th }}$ International Conference on Corpus Linguistics. May $31^{\text {st }}$ to June $2^{\text {nd }}$. Université Paris Diderot, Paris, France.

Lewin, Beverly A. (1998) Hedging: from and function in scientific research texts. In: Fortanet, Inmaculada (eds.) Genre Studies in English for Academic Purposes. Castelló de la Plana: Publicaciones de la Universitat Jaume I, 89-104. 
Lillis, Theresa (2017) Working with Ethnography to Explore Textual Practices. Seminar, University of Zaragoza, Spain, September $26^{\text {th }}, 2017$.

Lorés-Sanz, Rosa (2006) 'I will argue that': First person pronouns and metadiscoursal devices in research article abstracts in English and Spanish. ESP Across Cultures 3, 23-40.

Lorés-Sanz, Rosa (2008) Authorial visibility in research article and research article abstracts: the intergeneric perspective. In: Burgess, Sally and Martín-Martín, Pedro (eds.) English as an Additional Language in Research Publication and Communication. Berlin: Peter Lang, 105-122.

Lorés-Sanz, Rosa (2009) Different worlds, different audiences: a contrastive analysis of research article abstracts. In: Suomela-Salmi, Eija and Fred Dervin (eds.) Cross-linguistic and Crosscultural Perspectives on Academic Discourse. Amsterdam and Philadelphia: John Benjamins, 187-198.

Lorés-Sanz, Rosa (2011a) The construction of the author's voice in academic writing: the interplay of cultural and disciplinary factors. Text and Talk 31 (2), 173-193.

Lorés-Sanz, Rosa (2011b) The study of authorial voice: using a Spanish-English corpus to explore linguistic transference. Corpora 6 (1), 1-24.

Luzón Marco, María Jose (2000) Collocational framework in medical research papers: a genrebased study. English for Specific Purposes 19 (1), 63-86.

Martin, James R. and White, Michael (2005) The language of Evaluation: Appraisal in English. London: Palgrave.

Martínez, Iliana. A. (2001) Impersonality in the research article as revealed by analysis of the transitivity system. English for Specific Purposes 20 (3), 227-247.

Martínez, Iliana A. (2005) Native and non-native writer's use of first person pronouns in the different sections of biology research articles in English. Journal of Second Language Writing 14 (3), 174-190.

Matsuda, Paul K. (2001) Voice in Japanese written discourse: implications for second language writing. Journal of Second Language Writing 10 (1-2). University of New Hampshire, 35-53.

Matsuda, Paul and Tardy, Christine (2007) Voice in academic writing: The rhetorical construction of author identity in blind manuscript review. English for Specific Purposes 26 (2), 235-249.

Matsuda, Paul and Tardy, Christine (2008) Continuing the conversation on voice in academic writing. English for Specific Purposes 27 (1), 100-105.

Molino, Alessandra (2010) Personal and impersonal authorial references: A contrastive study of English and Italian linguistic research articles. English for Specific Purposes (9), 86-101.

Mur-Dueñas, Pilar (2007) 'I/we focus on...' A cross-cultural analysis of self-mentions in business management research articles". Journal of English for Academic Purposes 6 (2), 143-162.

Mur-Dueñas, Pilar and Jolanta Šinkūnienè (2016) Self-reference in research articles across Europe and Asia: A review of studies. Brno Studies in English 42 (1), 71-92.

Petrić, Bojana (2010) Students' conceptions of voice in academic writing. In: Lores-Sanz, Rosa, Mur-Dueñas, Pilar and Lafuente-Millan, Enrique (eds.) Constructing Interpersonality: Multiple Perspectives on Written Academic Genres. Cambridge: Cambridge Scholars Publishing, 324349.

Prince, Ellen, Frader, Joel and Bosk, Charles (1982) On Hedginng in Physicians-Physician Discourse. In Pietro, R. J. di (ed.) Linguistics and professions. Noordwood, New Jersey: Ablex, 83-97.

Prior, Paul (2001) Voices in text, mind, and society: sociohistoric accounts of discourse acquisitions and use. Journal of Second Language Writing 10 (1/2), 55-81.

Salager-Meyers, Françoise (1994) Hedges and Textual Communicative Function in Medical English Written Discourse. English for Specific Purposes 13 (2), 149-170.

Salager-Meyers, Françoise, Alcaraz Ariza, M. A. and Zambrano, N (2003) The scimitar, the dagger and the glove: Intercultural differences in the rhetoric of criticism in Spanish, French and English medical discourse (1930-1995). English for Specific Purposes 22 (3), 223-247.

Seoane, Elena and Hundt, M. (2018) Voice Alternation and Authorial Presence: Variation across Disciplinary Areas in Academic English. Journal of English Linguistics 46 (1), 3-22. 
Shaw, Philip (1992) Reasons for the correlation of Voice, Tense and Sentence Function in Reporting Verbs. Applied Linguistics 13 (3), 302-319.

Stapleton, Paul and Helms-Park, Rena (2008) A response to Matsuda and Tardy's 'Voice in academic writing: the rhetorical construction of author identity in blind manuscript reviews'. English for Specific Purpose 27, 94-99.

Stock, Ingrid and Eik-Nes, Nancy (2016) Voice features in academic texts - A review of empirical studies. Journal of English for Academic Purposes 24, 89-99.

Swales, John (1997) English as Tyrannosaurus rex. World Englishes 16 (3), 373-382.

Swales, John and Feak, Christine (2004) Academic Writing for Graduate Students: Essential Tasks and Skills. Michigan series in English for Academic and Professional Purposes.

Tang, Ramona and John, Suganthi (1999) The 'I' in identity: Exploring writer identity in student academic writing through the first person pronoun. English Specific Purposes 18, 23-39.

Tang, Ramona (2004) An Approach to Written Academic Voice: Exploring the Interpersonal Negotiations in Student Academic Writing through APPRAISAL. University of Birmingham. PhD Thesis (Unpublished).

Tardy, Christine (2004) The role of English in scientific communication: Lingua franca or Tyrannosaurus rex?. Journal of English for Academic Purposes 3, 247-269.

Tardy, Christine (2012) Current conceptions of voice. In: Hyland, Ken and Sancho Guinda, Carmen (eds.) Stance and Voice in Academic Discourse. Basingstoke: Palgrave Macmillan, 34-46.

Thomas, Sarah and Hawes, Thomas P. (1994) Reporting verbs in medical journal articles. English for Specific Purposes 13 (2), 129-148.

Vande Kopple, William J. (2002) Metadiscourse, discourse and issues in composition and rhetoric. In: Barton, Ellen and Stygall, Gail (eds.) Discourse Studies in Composition. New Jersey: Hampton Press, 91-113.

Varttala, Teppo (1999) Remarks on the communicative functions of hedging in popular scientific and specialist research articles on medicine. English for Specific Purposes 18 (2), 177-200.

\section{Appendix}

Med-RAs that constitute the corpus of this study

\begin{tabular}{|l|l|l|}
\hline Med-RA & \multicolumn{1}{|c|}{ Med-RAs titles } & \multicolumn{1}{|c|}{ Sources } \\
\hline 1 & $\begin{array}{l}\text { Fetal exposure to herpesviruses may be associated } \\
\text { with pregnancy-induced hypertensive disorders and } \\
\text { preterm birth in a Caucasian population }\end{array}$ & $\begin{array}{l}\text { BJOG An International } \\
\text { Journal of Obstetrics and } \\
\text { Gynaecology }\end{array}$ \\
\hline 2 & $\begin{array}{l}\text { Presence of depressive symptoms during early preg- } \\
\text { nancy and the risk of preterm delivery: a prospective } \\
\text { cohort study }\end{array}$ & Human Reproduction \\
\hline 3 & $\begin{array}{l}\text { Identification of Tuberculosis Susceptibility Genes } \\
\text { with } \\
\text { Human Macrophage Gene Expression Profiles }\end{array}$ & PlosPathogens \\
\hline 5 & $\begin{array}{l}\text { Predictors of driving safety in early Alzheimer disease } \\
\text { Predicting risk of type 2 diabetes in England and } \\
\text { Wales: prospective derivation and validation of QD- }\end{array}$ & Neurology \\
\hline 6 & $\begin{array}{l}\text { Comparing the Quality of the Suture Anastomosis } \\
\text { and the Learning Curves Associated with Performing } \\
\text { Open, Freehand, and Robotic-Assisted Laparoscopic } \\
\text { Pyeloplasty in a Swine Animal Model }\end{array}$ & $\begin{array}{l}\text { American College of Sur- } \\
\text { geons }\end{array}$ \\
\hline
\end{tabular}




\begin{tabular}{|c|c|c|}
\hline Med-RA & Med-RAs titles & Sources \\
\hline 7 & $\begin{array}{l}\text { Timing of initiation of antiretroviral therapy in AIDS- } \\
\text { free HIV-1-infected patients: a collaborative analysis } \\
\text { of } 18 \text { HIV cohort studies }\end{array}$ & The Lancet \\
\hline 8 & $\begin{array}{l}\text { Effectiveness of haemodialysis access with an autolo- } \\
\text { gous } \\
\text { tissue-engineered vascular graft: a multicentre cohort } \\
\text { study }\end{array}$ & The Lancet \\
\hline 9 & $\begin{array}{l}\text { A phase II study of weekly topotecan and docetaxel } \\
\text { in heavily treated patients with recurrent uterine and } \\
\text { ovarian cancers }\end{array}$ & Gynecol Oncol \\
\hline 10 & $\begin{array}{l}\text { Disorders of Balance and Vestibular Function in US } \\
\text { Adults }\end{array}$ & Arch. Intern. Med. \\
\hline 11 & $\begin{array}{l}\text { The Child Anxiety Prevention Study: Intervention } \\
\text { Model and Primary Outcomes }\end{array}$ & $\begin{array}{l}\text { Journal of Consulting and } \\
\text { Clinical Psychology }\end{array}$ \\
\hline 12 & $\begin{array}{l}\text { Aspirin in the primary and secondary prevention of } \\
\text { vascular disease: collaborative meta-analysis of indi- } \\
\text { vidual participant data from randomised trials }\end{array}$ & The Lancet \\
\hline 13 & $\begin{array}{l}\text { Perinatal Outcomes in Nutritionally Monitored Obese } \\
\text { Pregnant Women: A Randomized Clinical Trial }\end{array}$ & \begin{tabular}{|l|} 
Journal of the National \\
Medical Association \\
\end{tabular} \\
\hline 14 & $\begin{array}{l}\text { Higher serum folate levels are associated with a lower } \\
\text { risk of atopy and wheeze }\end{array}$ & J Allergy Clin Immunol \\
\hline 15 & $\begin{array}{l}\text { Prevalence, treatment, and associated disability of } \\
\text { mental disorders in four provinces in China during } \\
\text { 2001-05: an epidemiological survey }\end{array}$ & The Lancet \\
\hline 16 & $\begin{array}{l}\text { Mediterranean Diet, Alzheimer Disease, and Vascular } \\
\text { Mediation }\end{array}$ & Archives of Neurology \\
\hline 17 & $\begin{array}{l}\text { Interaction Between the Serotonin Transporter Gene } \\
(5-H T T L P R), \\
\text { Stressful Life Events, and Risk of Depression }\end{array}$ & $\begin{array}{l}\text { Journal of American Medi- } \\
\text { cal Association }\end{array}$ \\
\hline 18 & $\begin{array}{l}\text { Venom immunotherapy reduces large local reactions } \\
\text { to insect stings }\end{array}$ & J Allergy Clin Immunol \\
\hline 19 & $\begin{array}{l}\text { Effect of Gastric Bypass Surgery on Kidney Stone } \\
\text { Disease }\end{array}$ & The Journal of Urology \\
\hline 20 & $\begin{array}{l}\text { Contact With Beach Sand Among Beachgoers and } \\
\text { Risk of Illness }\end{array}$ & $\begin{array}{l}\text { American Journal of Epide- } \\
\text { miology }\end{array}$ \\
\hline 21 & $\begin{array}{l}\text { Changes in case fatality of aneurysmal subarachnoid } \\
\text { haemorrhage over time, according to age, sex, and } \\
\text { region: a meta-analysis }\end{array}$ & The Lancet \\
\hline 22 & $\begin{array}{l}\text { Bone Mineral Density in Estrogen-Deficient Young } \\
\text { Women }\end{array}$ & J Clin Endocrinol Metab \\
\hline 23 & $\begin{array}{l}\text { Rates of Serious Infection after Changes in Regimens } \\
\text { for Medical Abortion }\end{array}$ & $\begin{array}{l}\text { New England Journal of } \\
\text { Medicine }\end{array}$ \\
\hline 24 & $\begin{array}{l}\text { Prevalence and Repair of Intraoperatively Diagnosed } \\
\text { Patent Foramen Ovale and Association With Periop- } \\
\text { erative Outcomes and Long-term Survival }\end{array}$ & $\begin{array}{l}\text { Journal of American Medi- } \\
\text { cal Association }\end{array}$ \\
\hline 25 & $\begin{array}{l}\text { A Pooled Analysis of the Effect of Condoms in Pre- } \\
\text { venting HSV-2 Acquisition }\end{array}$ & Arch Intern Med. \\
\hline
\end{tabular}




\begin{tabular}{|c|c|c|}
\hline Med-RA & Med-RAs titles & Sources \\
\hline 26 & $\begin{array}{l}\text { Use of fertility drugs and risk of ovarian cancer: Dan- } \\
\text { ish population based cohort study }\end{array}$ & $B J M$ \\
\hline 27 & Hormone Therapy and Ovarian Cancer & $\begin{array}{l}\text { Journal of American Medi- } \\
\text { cal Association }\end{array}$ \\
\hline 28 & $\begin{array}{l}\text { High Levels of CirculatingVEGFR2+ Bone Marrow } \\
\text {-Derived Progenitor Cells Correlate with Metastatic } \\
\text { Disease in Patients with Pediatric Solid Malignancies }\end{array}$ & Clin Cancer Res \\
\hline 29 & $\begin{array}{l}\text { Parenting stress and psychological functioning among } \\
\text { mothers of preschool children with autism and devel- } \\
\text { opmental delay }\end{array}$ & Autism \\
\hline 30 & $\begin{array}{l}\text { Evolution and Survival on Eutherian Sex Chromo- } \\
\text { somes }\end{array}$ & Plos Genetics \\
\hline 31 & $\begin{array}{l}\text { Positive and Negative Religious Coping and Well- } \\
\text { Being in Women with Breast Cancer }\end{array}$ & $\begin{array}{l}\text { Journal of Palliative Medi- } \\
\text { cine }\end{array}$ \\
\hline 32 & $\begin{array}{l}\text { Prenatal Airborne Polycyclic Aromatic Hydrocarbon } \\
\text { Exposure and Child IQ at Age } 5 \text { Years }\end{array}$ & Pediatrics \\
\hline 33 & $\begin{array}{l}\text { Exposure to Tobacco on the Internet: Content Analysis } \\
\text { of Adolescents' Internet Use }\end{array}$ & Pediatrics \\
\hline 34 & $\begin{array}{l}\text { Phosphorus and Potassium Content of Enhanced Meat } \\
\text { and Poultry Products: Implications for Patients Who } \\
\text { Receive Dialysis }\end{array}$ & Clin J Am Soc Nephrol \\
\hline 35 & $\begin{array}{l}\text { Repeated measures of serum glucose and insulin in } \\
\text { relation to postmenopausal breast cancer }\end{array}$ & Int. J. Cancer. \\
\hline 36 & $\begin{array}{l}\text { When to Start Antiretroviral Therapy in Resource- } \\
\text { Limited Settings }\end{array}$ & Ann Intern Med. \\
\hline 37 & $\begin{array}{l}\text { Peginterferon Alfa-2b or Alfa-2a with Ribavirin for } \\
\text { Treatment of Hepatitis C Infection }\end{array}$ & N Engl J Med \\
\hline 38 & $\begin{array}{l}\text { Surgical Mask vs N95 Respirator for Preventing Influ- } \\
\text { enza Among Health Care Workers }\end{array}$ & $\begin{array}{l}\text { Journal of American Medi- } \\
\text { cal Association }\end{array}$ \\
\hline 39 & $\begin{array}{l}\text { Exposure to Fine Particulate Matter and Acute Effects } \\
\text { on Blood Pressure: Effect Modification by Measures } \\
\text { of Obesity and Location }\end{array}$ & $\begin{array}{l}\text { Journal of Epidemiology } \\
\text { and Community Health }\end{array}$ \\
\hline 40 & $\begin{array}{l}\text { Critically Ill Patients With } 2009 \text { Influenza A(H1N1) } \\
\text { Infection in Canada }\end{array}$ & $\begin{array}{l}\text { Journal of American Medi- } \\
\text { cal Association }\end{array}$ \\
\hline
\end{tabular}

IsABel Herrando-Rodrigo is a lecturer in the Department of English and German Studies at the Universidad de Zaragoza (Spain) where she teaches language and linguistics. Her research interests focus on written discourse analysis, writers' visibility, genre analysis and digital genres. She is a member of the research group CIRES (International Communication and Social Challenges CIRES H16_17R) and she is currently participating in the national research project FFI2017-84205-R.

Address: Isabel Herrando-Rodrigo, Departamento de Filología Inglesa y Alemana, Facultad de Filosofía y Letras, Universidad de Zaragoza, C/San Juan Bosco 7, 50.009 Zaragoza, Spain. [e-mail: herrando@unizar.es] 